\title{
Simulation of Sandsage-Bluestem Forage Growth Under Varying Stocking Rates
}

\author{
S. G. K. Adiku, ${ }^{1}$ G. H. Dunn, ${ }^{2}$ L. R. Abuja, ${ }^{3}$ S. Gunter, ${ }^{4}$ J. Bradford, ${ }^{5}$ L. Garcia, ${ }^{6}$ and A. A. Andales ${ }^{7}$ \\ Authors are ${ }^{1}$ Soil Scientist, Department of Civil and Environmental Engineering, Colorado State University, Fort Collins, CO 80523, USA; ${ }^{2}$ Soil Scientist \\ and ${ }^{3}$ Soil Scientist and Research Leader, US Department of Agriculture, Agricultural Research Service (USDA-ARS), Agricultural Systems Research Unit, \\ Fort Collins, CO 80526, USA; ${ }^{4}$ Range Scientist and Research Leader and ${ }^{5}$ Range Scientist, USDA-ARS, Southern Plains Range Research Station, Ft. \\ Supply, OK 73801, USA; ${ }^{6}$ Professor and Head, Department of Civil and Environmental Engineering, Colorado State University, Fort Collins, CO 80523, \\ USA; and ${ }^{7}$ Assistant Professor, Department of Soil and Crops, Department of Soil and Crops, Colorado State University, Fort Collins, CO 80523, USA.
}

\begin{abstract}
The effect of stocking rate on forage growth has attracted much research attention in forage science. Findings show that forage growth may be affected by stocking rate, and there is a consensus that high stocking rates lead to soil compaction, which could also in turn affect forage growth because of the changing soil hydrology and increased soil impedance to forage root penetration. In this study we used a modeling approach to investigate the effect of stocking rates on the growth of sand-bluestem forage at Fort Supply, Oklahoma. The GPFARM-Range model, which was originally developed and validated for Cheyenne, Wyoming, was recalibrated and enhanced to simulate soil compaction effects on forage growth at Fort Supply. Simulations without the consideration of soil compaction effects overestimated the forage growth under high stocking rate conditions (mean bias $[\mathrm{MBE}]=-591 \mathrm{~kg} \cdot \mathrm{ha}^{-1}$ ), and the agreement between the simulated and observed forage growth was poor (Willmott's $d=0.47)$. The implementation in the model of soil compaction effects associated with high stocking rates reduced the bias $\left(\mathrm{MBE}=-222 \mathrm{~kg} \cdot \mathrm{ha}^{-1}\right)$ and improved the overall agreement between the observed and the simulated forage growth $(d=0.68)$. It was concluded that forage growth under increasing soil compaction could be predicted provided such sensitivities are included in forage growth models.
\end{abstract}

\section{Resumen}

El efecto de la carga animal sobre el crecimiento del forraje ha suscitado mucha investigación en el área de la ciencia del forraje. Los resultados demuestran que el crecimiento del forraje puede ser afectado por la carga animal y existe consenso de que las altas cargas animales devienen en la compactación del suelo que a su vez afecta el crecimiento del forraje mediante cambios en la hidrología edáfica y un incremento en la resistencia del suelo a la penetración de las raíces de especies forrajeras. En este ensayo, utilizamos un enfoque de modelación para investigar el efecto de la carga animal sobre el crecimiento de forraje de Andropogon sallii en Fort Supply, Oklahoma. El modelo GPFARM-Range originalmente desarrollado y validado para las condiciones de Cheyenne, Wyoming, fue re-calibrado y mejorado para simular los efectos de la compactación del suelo sobre el crecimiento del forraje en Fort Supply. Las simulaciones que no consideraron los efectos de la compactación del suelo sobreestimaron el crecimiento del forraje en condiciones de alta carga animal (sesgo promedio $[\mathrm{MBE}]=-591 \mathrm{~kg} \cdot \mathrm{ha}^{-1}$ ) y la correspondencia entre el crecimiento de forraje simulado y observado fue baja ( $d$ de Willmott $=0.47$ ). La inclusión de los efectos de la compactación del suelo en el modelo redujeron el sesgo $\left(\mathrm{MBE}=-222 \mathrm{~kg} \cdot \mathrm{ha}^{-1}\right)$ y también mejoró la correspondencia general el crecimiento de forraje simulado y observado $(d=0.68)$. Se concluyó que el crecimiento del forraje en condiciones de compactación creciente del suelo podría ser predicho siempre y cuando la sensibilidad del forraje a dicha compactación se incluya en los modelos de crecimiento.

Key Words: forage growth, modeling, soil compaction, stocking rate

\section{INTRODUCTION}

Long-term evaluation of rangeland conditions across the Great Plains of the United States indicates that forage growth and rangeland condition are affected by stocking rate. The analysis by Holechek et al. (1999) of 25 studies showed that the average forage productions under heavy grazing (57\% forage usage), moderate grazing (43\% usage), and light grazing (32\% usage) were $1316 \mathrm{~kg} \cdot \mathrm{ha}^{-1}, 1649 \mathrm{~kg} \cdot \mathrm{ha}^{-1}$, and $1788 \mathrm{~kg} \cdot \mathrm{ha}^{-1}$, respectively. The findings also indicated a general downward

Correspondence: S. G. K. Adiku, Dept of Civil and Environmental Engineering, Colorado State University, Fort Collins, CO 80523, USA. Email: sadiku@mail.colostate.edu

Manuscript received 16 October 2009; manuscript accepted 2 May 2010. ecological condition under heavy grazing but opposite for moderate and light grazing.

Even though other studies also concluded that chronic intensive grazing was detrimental to forage primary productivity and plant survival (Briske et al. 2008), findings differ from site to site. For example, Derner and Hart (2007) analyzed $16 \mathrm{yr}$ of forage growth data on a northern mixed grass prairie from exclosure, low ( 5 ha $\cdot$ steer $^{-1}$ ) and high (2.25 ha $\cdot$ steer $^{-1}$ ) stocking rates, and showed that though growth declined with increasing stocking rate, the differences were not significant. Gillen and Sims (2004) also reported on forage growth during the last $4 \mathrm{yr}$ of a 20-yr (1941-1961) grazing study under three stocking rates of $5 \mathrm{ha} \cdot$ steer $^{-1}$ (low), 4 ha $\cdot$ steer $^{-1}$ (moderate), and 3 ha $\cdot$ steer $^{-1}$ (high) at Ft. Supply, Oklahoma. Their findings showed that there were no 
significant differences among stocking rate effects on the total forage or individual species growth. Milchunas and Lauenroth (1993) concluded that there was only a weak relationship between grazing intensity and above-ground forage production.

Whereas the findings relating to stocking rate and forage growth may differ from site to site, presumably because of ecological differences, the bulk of evidence indicates a deterioration of soil properties under high stocking rates. Heavily grazed sites are often found to become compacted, a situation that leads to a reduction in macroporositiy and decreased infiltration (Drewry 2008), increased runoff (Hanson et al. 1970; Blackburn 1975), and accelerated erosion. For the Ft. Supply studies reported by Gillen and Sims (2004), Rhoades et al. (1964) showed that the top soil $(0-15 \mathrm{~cm})$ bulk density (BD) at the end of the $20-\mathrm{yr}$ period was $1.61 \mathrm{~g} \cdot \mathrm{cm}^{-3}$ and $1.70 \mathrm{~g} \cdot \mathrm{cm}^{-3}$ for the low and high stocking rate fields, respectively. In comparison, the average top soil $\mathrm{BD}$ of the nongrazed exclosure was $1.49 \mathrm{~g} \cdot \mathrm{cm}^{-3}$. Associated with the increased BD of the grazed fields was a decline in the infiltration rates from $115 \mathrm{~mm} \cdot \mathrm{h}^{-1}$ for the low stocking rate to $58 \mathrm{~mm} \cdot \mathrm{h}^{-1}$ for the high stocking rate. In addition to altering soil hydraulic properties (Assouline 2006) and hence altering the soil water availability to forage plant growth, soil compaction also increases the sheer soil strength and impedance (Battikhi and Suleiman 1999), thereby reducing root penetration. As a consequence, the overall plant growth may be significantly affected by increased soil BD (Abdel-Magid et al. 1987; Mapfumo et al. 1998). Barton et al. (1966) observed a decline in forage yield as the strength of the compacted soil layer increased. Donkor et al. (2002) observed increased soil compaction and forage growth decline under high stocking rate. Despite the nonsignificance of stocking rate effect on forage growth at Ft. Supply as reported by Gillen and Sims (2004), there was a tendency of growth reduction from $1540 \mathrm{~kg} \cdot \mathrm{ha}^{-1}$ to $1450 \mathrm{~kg} \cdot \mathrm{ha}^{-1}$ as stocking rate increased from low to high. For forbs in particular, growth declined from $200 \mathrm{~kg} \cdot \mathrm{ha}^{-1}$ to $120 \mathrm{~kg} \cdot \mathrm{ha}^{-1}$ when stocking rate increased from low to high.

It is of practical interest to predict if continuous high stocking rates would eventually lead to reduced forage growth as a result of compaction. Timely knowledge of this effect could help decision makers and ranchers adjust to stocking rates to prevent forage deterioration. Forage growth models could become useful in investigating such complex soil-plant-animal interactions provided the models have the sensitivity to mimic soil compaction effects in addition to other environmental stresses. The Great Plains Framework for Agricultural Resource Management (GPFARM)-Range model (Andales et al. 2005, 2006) was developed for simulating forage and animal growth under varying soil and environmental conditions in the Great Plains of the United States. The model was successfully validated at Nunn, Colorado, and Cheyenne, Wyoming. Although the model can account for a host of factors that affect forage growth such as soil water, temperature, and preferential grazing, it lacks the sensitivity to mimic the effects of soil compaction on forage growth. The aim of this study was twofold. First, we sought to calibrate and validate the GPFARM-Range model for simulating forage growth at Ft. Supply, Oklahoma. Second, we evaluated the gains in forage growth simulation accuracy due to the inclusion of a soil compaction index into the model.

\section{MATERIALS AND METHODS}

\section{Site and Datasets}

The site for this study was the Southern Plains Experimental Range (SPER), Ft. Supply, Oklahoma (long $99.39^{\circ} \mathrm{W}$, lat $36.42^{\circ} \mathrm{N}$ ), where stocking rate studies were conducted from 1941 to 1961 . The average rainfall is $576 \mathrm{~mm}$ with about $77 \%$ falling from April to October. The soils are classified as Typic Haplustepts with coarse loamy sand, carrying a dominant vegetation of sandsage-bluestem (Artemesia-Adropogon) (Küchler 1975). The details of the studies can be found in Rhoades et al. (1964) and Gillen and Sims (2004). Briefly, the experimental range was divided into three pastures of 1 ) low stocking zone (L), 2) moderate stocking zone (M), and 3) heavy stocking zone $(\mathrm{H})$, with sections within each zone fenced to exclude grazing, giving a total of six treatments (Table 1). Replicated grazing treatments were initiated in 1941 and continued for $20 \mathrm{yr}$. The exclosures were relocated annually to capture the effect of previous years' grazing on current forage regrowth potential. In 1961 several soil properties including the bulk density was determined in each treatment. Our current study focused on a 5-yr period from 1953 to 1957 for which detailed forage data were available to us. The actual stocking rates were adjusted from year to year in each treatment, depending on the seasonal rainfall but on the average, these were $5.0 \mathrm{ha} \cdot$ steer $^{-1}, 4.0 \mathrm{ha} \cdot$ steer $^{-1}$, and $3.0 \mathrm{ha} \cdot$ steer $^{-1}$ for the low, moderate, and high stocking, respectively (Table 1 ). The steers, which had an initial average weight of $213 \mathrm{~kg}$, were kept for $320 \mathrm{~d}$ ( 13 November to 29 September) on the forage. Live forage was measured for each treatment, from April to November at approximately monthly intervals.

\section{Model Description}

The GPFARM-Range model simulates the growth of forage and grazing animals. Both the forage and animal components have been previously validated at Cheyenne, Wyoming, and Nunn, Colorado (Andales et al. 2005, 2006). The forage component of the model simulates the growth of up to five functional groups: 1) warm season grass (WSG), 2) cool season grass, 3) legumes, 4) shrubs, and 5) forbs, under varying environment and grazing management conditions. During the 5 yr of study (1953-1957), we focused mainly on the WSG, which was the dominant $(85 \%)$ functional group at Ft. Supply, and forbs, even though this constituted a small proportion $(15 \%)$. The daily growth of a given functional group, $i, \Delta W_{i}$

Table 1. Datasets used for the simulation studies.

\begin{tabular}{lclc}
\hline Stocking zone & Treatment $^{1}$ & Description & Stocking rate $\left(\right.$ ha $\cdot$ steer $^{-1}$ ) \\
\hline Low $(\mathrm{L})$ & LNG & Exclosure & 0.0 \\
& LGR & Grazed & 5.0 \\
\multirow{2}{*}{ Moderate (M) } & MNG & Exclosure & 0.0 \\
& MGR & Grazed & 4.0 \\
Heavy (H) & HNG & Exclosure & 0.0 \\
& HGR & Gazed & 3.0 \\
\hline
\end{tabular}

${ }^{1}$ LNG indicates low stocking non-grazed forage; LGR, low stocking grazed forage; MNG, moderate stocking non-grazed forage; MGR, moderate stocking grazed forage; HNG, heavy stocking non-grazed forage; and HGR, heavy stocking grazed forage. 
Table 2. Input parameters for the model.

\begin{tabular}{|c|c|c|c|c|}
\hline Parameter & Definition & Low stock zone & Moderate stock zone & High stock zone \\
\hline \multicolumn{5}{|l|}{ Soil } \\
\hline Soil textural class & - & Loamy sand & Loamy sand & Loamy sand \\
\hline$\%$ sand & - & 71.0 & 71.0 & 71.0 \\
\hline$\%$ clay & - & 11.5 & 11.5 & 11.5 \\
\hline Bulk density (BD; 0-0.15 m) & - & 1.61 & 1.63 & 1.70 \\
\hline Porosity ${ }^{1}$ & - & 0.40 & 0.38 & 0.35 \\
\hline Ksat $\left(\mathrm{cm} \cdot \mathrm{hr}^{-1}\right)^{1}$ & Saturated hydraulic conductivity & 4.01 & 3.47 & 2.16 \\
\hline$h_{\mathrm{e}}(\mathrm{cm})^{1}$ & Air entry potential & -10.94 & -11.70 & -14.55 \\
\hline$\lambda^{1}$ & Pore distribution parameter & 0.40 & 0.41 & 0.42 \\
\hline \multicolumn{5}{|l|}{ Plant } \\
\hline \multicolumn{5}{|l|}{ Warm season grass } \\
\hline $\operatorname{GrRate}\left(\mathrm{kg} \cdot \mathrm{kg}^{-1} \cdot \mathrm{d}^{-1}\right)$ & Potential growth rate & 0.20 & 0.19 & 0.17 \\
\hline $\operatorname{Max} T\left({ }^{\circ} \mathrm{C}\right)$ & Maximum temperature & 45.0 & 45.0 & 45.0 \\
\hline$O p t T\left({ }^{\circ} \mathrm{C}\right)$ & Optimum temperature & 37.0 & 37.0 & 37.0 \\
\hline Tbase $\left({ }^{\circ} \mathrm{C}\right)$ & Base temperature & 9.0 & 9.0 & 9.0 \\
\hline RespRate $\left(\mathrm{kg} \cdot \mathrm{kg}^{-1} \cdot \mathrm{d}^{-1}\right)$ & Respiration rate & 0.04 & 0.04 & 0.04 \\
\hline$E W P$ & Water stress sensitivity factor & 0.15 & 0.15 & 0.15 \\
\hline \multicolumn{5}{|l|}{ Forb } \\
\hline GrRate $\left(\mathrm{kg} \cdot \mathrm{kg}^{-1} \cdot \mathrm{d}^{-1}\right)$ & Potential growth rate & 0.14 & 0.13 & 0.12 \\
\hline $\operatorname{MaxT}\left({ }^{\circ} \mathrm{C}\right)$ & Maximum temperature & 35.0 & 35.0 & 35.0 \\
\hline OptT $\left({ }^{\circ} \mathrm{C}\right)$ & Optimum temperature & 23.0 & 23.0 & 23.0 \\
\hline $\operatorname{MinT}\left({ }^{\circ} \mathrm{C}\right)$ & Minimum temperature & 3.0 & 3.0 & 3.0 \\
\hline RespRate $\left(\mathrm{kg} \cdot \mathrm{kg}^{-1} \cdot \mathrm{d}^{-1}\right)$ & Respiration rate & 0.04 & 0.005 & 0.04 \\
\hline$E W P$ & Water stress sensitivity factor & 0.25 & 0.25 & 0.25 \\
\hline
\end{tabular}

${ }^{1}$ BD-dependent parameters estimated from pedo-transfer functions.

$\left(\mathrm{kg} \cdot \mathrm{ha}^{-1} \cdot \mathrm{d}^{-1}\right)$, was described as

$$
\Delta W_{i}=\text { GrRate }_{i} \cdot \text { AboveBio }_{i} \cdot \mathrm{EVP}_{i},
$$

where GrRate $_{i}$ is potential growth rate $\left(\mathrm{kg} \cdot \mathrm{kg}^{-1} \cdot \mathrm{d}^{-1}\right)$, AboveBio $_{i}$ is above-ground live biomass $\left(\mathrm{kg} \cdot \mathrm{ha}^{-1}\right)$, and $E V P_{i}$ is an environmental fitness factor $(0-1)$ affecting forage production. The $E V P_{i}=E T P_{i} \cdot E W P_{i}$, where $E T P_{i}$ and $E W P_{i}$ are, respectively, the temperature and soil water effect on the growth of functional group $i$. The daily growth was further discounted for maintenance respiration, estimated as a fixed proportion (RespRate R $_{i}$ ) of the standing above-ground biomass. The net daily growth, which is obtained as the difference between the gross growth and respiration, is partitioned between the shoot and roots, following Hanson et al. (1987). For all the functional groups, propagation is assumed to be vegetative, recruiting reserves from the roots to initiate new growth at the commencement of each season. Forage demand by grazing animals is based on the metabolic weight of the animals as well as maintenance requirements and expressed in terms of the daily required total digestible nutrients (Andales et al. 2005).

The water balance component of the model was based on the RZWQM (Ahuja et al. 2000). Briefly, the description of soil evaporation and transpiration follows the approach of Shuttleworth and Wallace (1985) as modified by Farahani and Ahuja (1996) to account for sparse vegetation as well as bare patches that are common in rangelands. Infiltration into the soil follows Green and Ampt (1911). The description of the soil hydraulic properties follows Brooks and Corey (1964), and water flow follows Darcy. Porosity is derived from the BD, which in turn affects the soil hydraulic properties such as water retention and the hydraulic conductivity (Table 2).

\section{Formulation of Soil Compaction Effects on Forage Growth}

Our approach to introduce soil compaction sensitivity into the model is based on earlier observations by Abdel-Magid et al. (1987) and Mapfumo et al. (1998). Both groups of authors

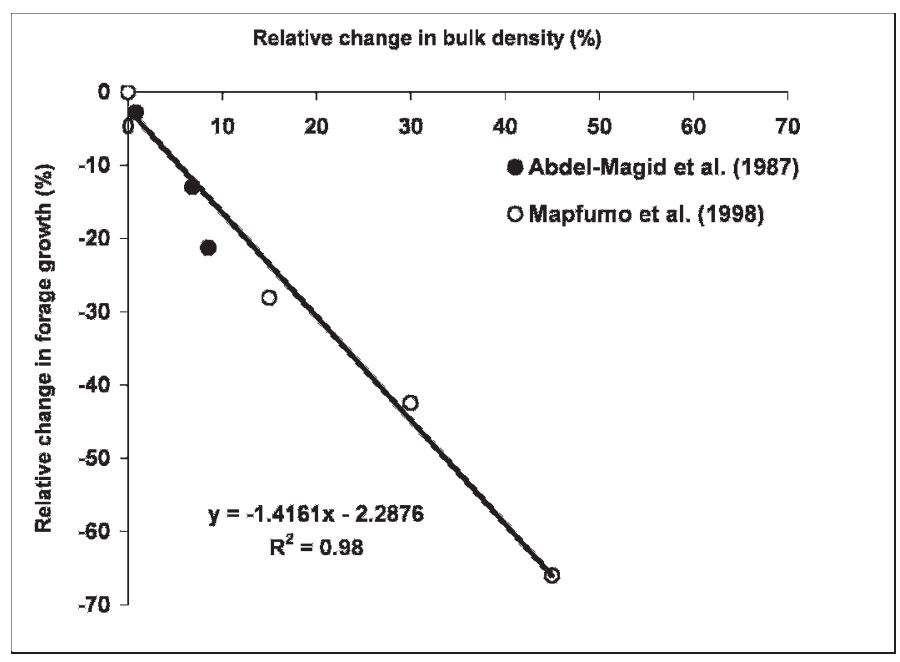

Figure 1. Relative change in forage growth in response to bulk density increase. 
investigated the decline in forage growth under increased soil BD. Using their data, it could be shown that the plot of the relative decline in forage growth with the relative increase in the BD yielded a linear curve (Fig. 1) that could be described by

$$
\frac{\Delta W}{W_{\text {ref }}}=-1.42 \cdot \frac{\Delta B D}{B D_{\text {ref }}}-2.29, \quad r^{2}=0.98,
$$

where $\Delta W / W_{\text {ref }}$ and $\triangle B D / B D_{\text {ref }}$ are the percent changes in forage growth and bulk density, respectively. $W_{\text {ref }}$ is the nonlimiting forage growth, and $B D_{\text {ref }}$ is the nonlimiting $\mathrm{BD}$, taken as that for the low stocking rate. Since forage growth is determined by the GrRrate (see equation 1), equation 2 was applied directly to modify the growth rate parameter as the BD changed.

\section{Model Inputs}

The meteorological input data for the model included the daily maximum and minimum temperature, wind speed, rainfall, relative humidity, and solar radiation. These data, except solar radiation, were obtained from Ft. Supply, Oklahoma. Solar radiation data were estimated from the daily maximum and minimum temperature and latitude, and the extraterrestrial radiation using algorithms of Hargreaves and Samani (1982). The detail soil profile texture and BD data were obtained from the Natural Resources Conservation Service database. For the top $15 \mathrm{~cm}$, the input $\mathrm{BD}$ values were those reported for each stocking rate by Rhoades et al. (1964). The plant growth and development input parameters for the WSG and forbs are summarized in Table 2 (lower portion). There were no appreciable cool season grasses at the grazed sites.

\section{Model Calibration and Validation}

The GPFARM-Range model was recalibrated for the Fort Supply site using the monthly total forage growth data from the exclosure at the low stocking zone (LNG). In doing so, the plant parameters in the model were adjusted to get the best fit of the total biomass curve. The plant and soil parameter values considered adequate in this regard are summarized under "Low stock zone" in Table 2. Further, the BD values were used to determine the appropriate soil hydraulic properties for each stocking zone via pedo-transfer equations available in the GPFARM-Range model (Table 2). Also, equation 2 was used to modify the GrRate in equation 1 for each zone depending on the $\mathrm{BD}$. This led to a $0 \%, 5 \%$, and $11 \%$ decrease in the GrRate for the low, moderate, and high stocking zones, respectively (Table 2).

For validation, the model was executed under two situations: without $(\mathrm{Sim}-\mathrm{BD})$ or with $(\mathrm{Sim}+\mathrm{BD})$ soil compaction effects on forage growth. The Sim-BD assumed that the plant parameters were unaffected by soil compaction, although total forage removal by grazing differed with stocking rate. In the case of Sim+BD, all the factors, namely, the soil hydraulic properties, GrRate, and forage removal by grazing differed with soil compaction and stocking rate. The observed validation data sets were those reported for the remaining treatments LGR to HGR (Table 1). The agreement between the simulated and observed forage growth was based on statistical measures such as correlation coefficient $(r)$, the mean bias error, root mean square error, and the Willmott $d$-index
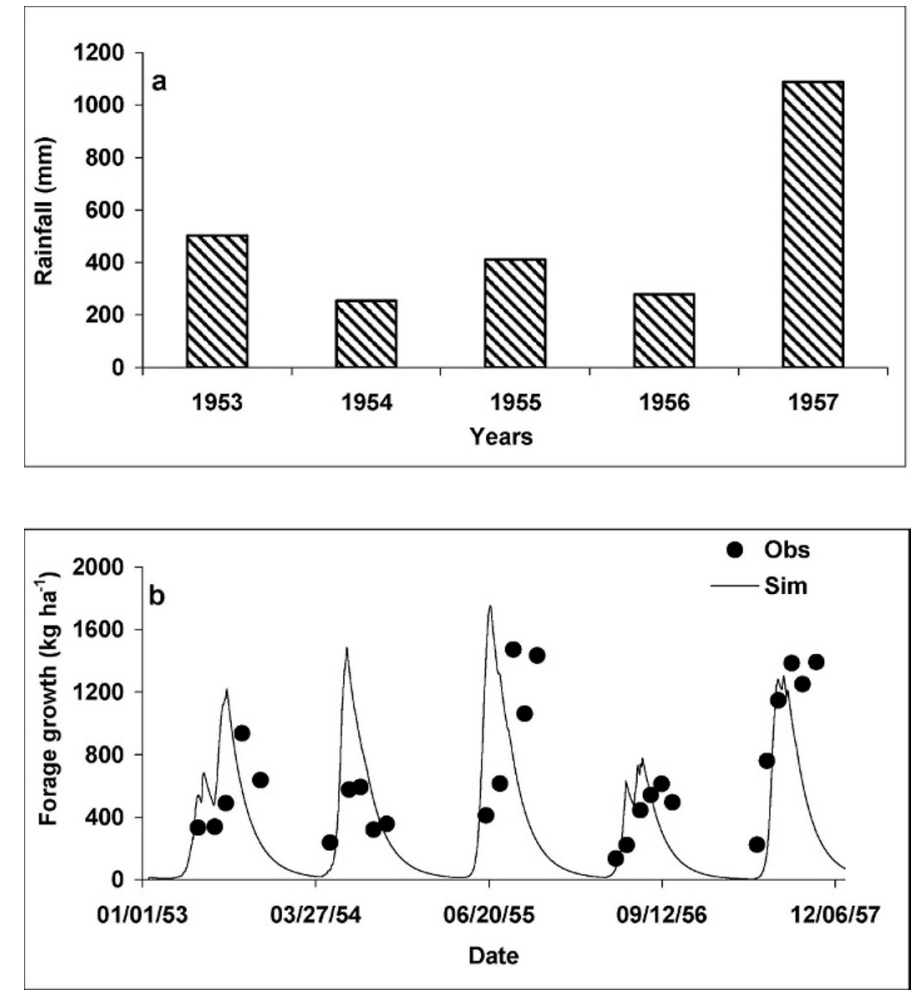

Figure 2. Rainfall during the study period (a) and the observed (symbols) and simulated (line) forage growth for model calibration (b).

(Willmott 1981). The Willmott $d$-index is a model efficiency index defined as

$$
d=1-\left[\frac{\sum_{i=1}^{i=n}\left(p_{i}-o_{i}\right)^{2}}{\sum\left(\left|p_{i}^{\prime}\right|+\left|o_{i}^{\prime}\right|\right)^{2}}\right] \quad 0 \leq d \leq 1,
$$

where $p_{i}$ and $o_{i}$ are the predicted and observed forage, respectively, $p^{\prime}{ }_{i}=p_{i}-\overline{\mathrm{o}}, o_{i}{ }^{\prime}=o_{i}-\overline{\mathrm{o}}$, with $\overline{\mathrm{o}}$ being the observed mean. A perfect agreement between the predicted and the observed is indicated by a $d$-index of 1 .

\section{RESULTS}

\section{Model Calibration}

The time course of the simulated and the observed forage growth for the calibration dataset LNG is shown in Figure 2. Growth varied from year to year following the rainfall pattern generally. Forage growth declined from 1953 to 1954, increased in 1955, with a sharp decline in 1956 and a recovery in 1957. The model could mimic the observed growth patterns, especially the sharp decline in 1956 and the recovery in 1957. However, the model overestimated the growth in 1954. The agreement between the simulated and the observed was satisfactory $\left(r^{2}=0.64\right.$; not shown $)$.

\section{Model Validation}

The observed forage growth in the exclosures under the moderate and high stocking rates followed the patterns 

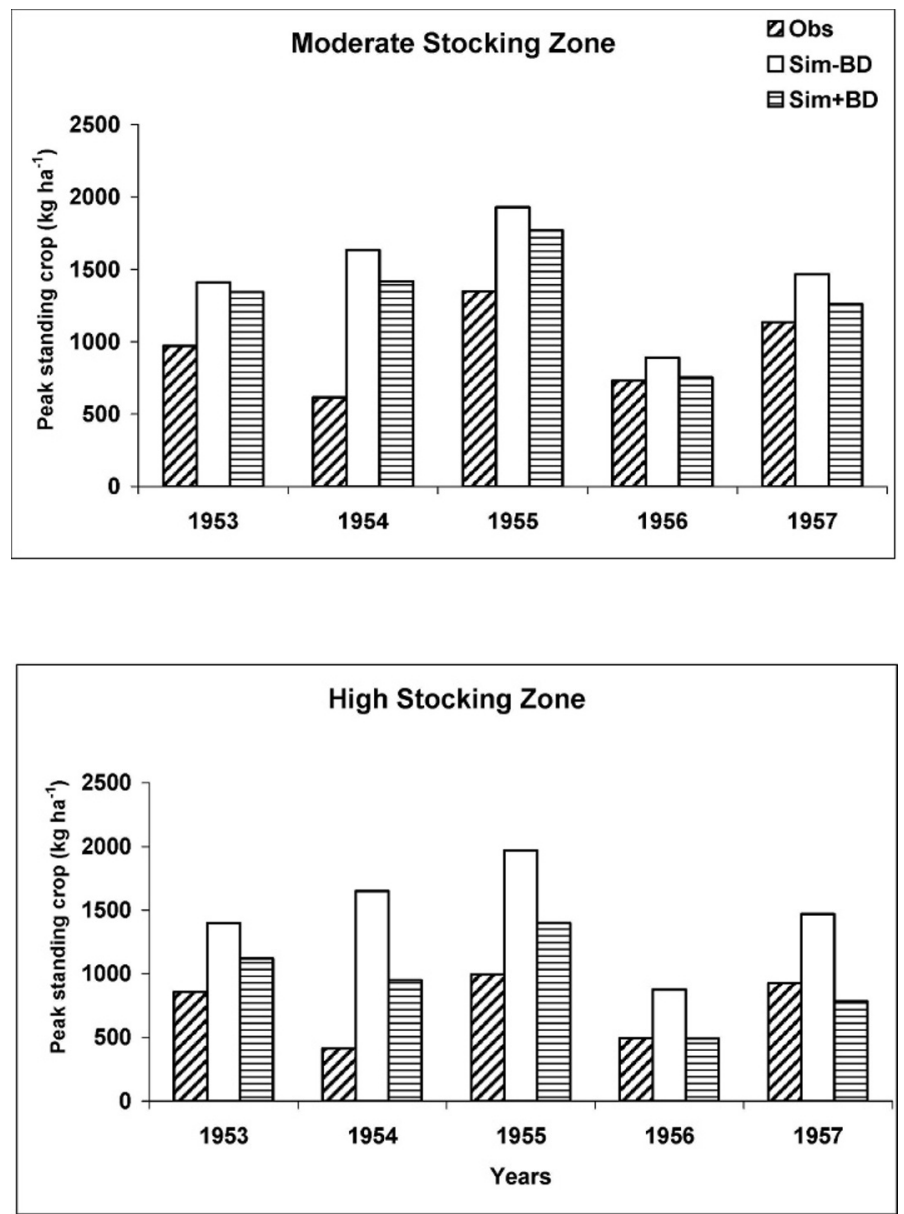

Figure 3. Observed (Obs) and simulated peak standing crop for exclosures without $(\mathrm{Sim}-\mathrm{BD})$ and with $(\mathrm{Sim}+\mathrm{BD})$ soil compaction effects.

described for the calibration dataset (Fig. 3). The Sim-BD simulations, which neglected any soil compaction impact, overestimated the forage growth. Though the forage in an exclosure was not grazed within any given year, the cumulative trampling effects over time would alter the soil properties. The Sim+BD simulated the peak standing crop (PSC) better and tended to agree more with the observations, especially at the high stocking zone.

The interaction between soil compaction and grazing appeared to reduce forage growth. For the low stocking zone (Fig. 4, top panel), the PSC in all the years was slightly lower than those under exclosure (Fig. 2b), but the difference may not be significant. The Sim-BD and Sim+BD overestimated the PSC in $3 \mathrm{yr}$ out of $5 \mathrm{yr}$. The two simulations were similar because of the assumption that the $\mathrm{BD}$ for low stocking zone was nonlimiting to forage growth (see section on formulation soil compaction index). Under the moderate (Fig. 4, middle panel) and high (Fig. 4, bottom panel) stocking conditions, the Sim+BD simulated the forage growth better than the Sim-BD. The comparisons between the simulated and observed forage growth (Fig. 5) showed that the inclusion of the soil compaction effect in the model led to a reduction in the mean bias from $-591 \mathrm{~kg} \cdot \mathrm{ha}^{-1}$ to $-222 \mathrm{~kg} \cdot \mathrm{ha}^{-1}$ and increased the Willmott $d$-index from 0.47 to 0.68 .
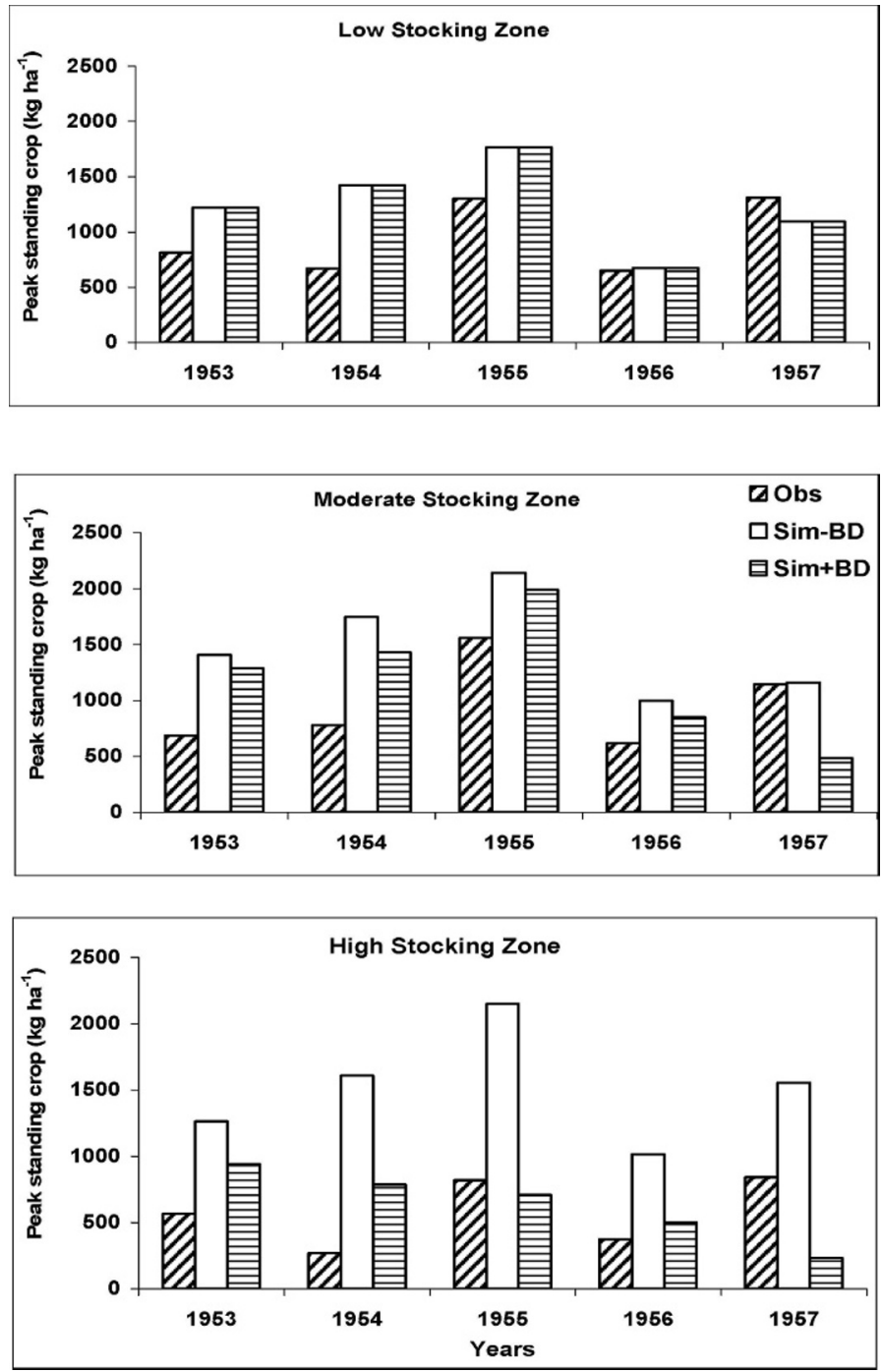

Figure 4. Observed (Obs) and simulated peak standing crop for grazed conditions without $(\mathrm{Sim}-\mathrm{BD})$ and with $(\mathrm{Sim}+\mathrm{BD})$ soil compaction effects.

\section{DISCUSSION}

The limited recalibration of the GPFARM-Range model showed that the model could be extended to conditions at Ft. Supply to simulate forage growth in exclosures and under low stocking rate conditions. As stocking rates increased, there was the need to adjust soil properties and plant parameters accordingly to reflect possible changes to soil and plant growth. For the soil hydrology, the input of the correct stocking rate-related BD could account for the changes in water availability and water stress effects. In the case of forage growth response to $\mathrm{BD}$, the derived relationship in equation 2 , though based on limited data, appeared to have improved the forage growth simulations. However, more experimental data are required to strengthen this relationship.

The extent to which forage growth is affected by soil compaction would depend on 1) the magnitude of the trampling-induced $\mathrm{BD}$ change and 2) the sensitivity of the forage species to compaction. The BD dynamics would depend on factors such as soil texture, trampling load, and recovery 

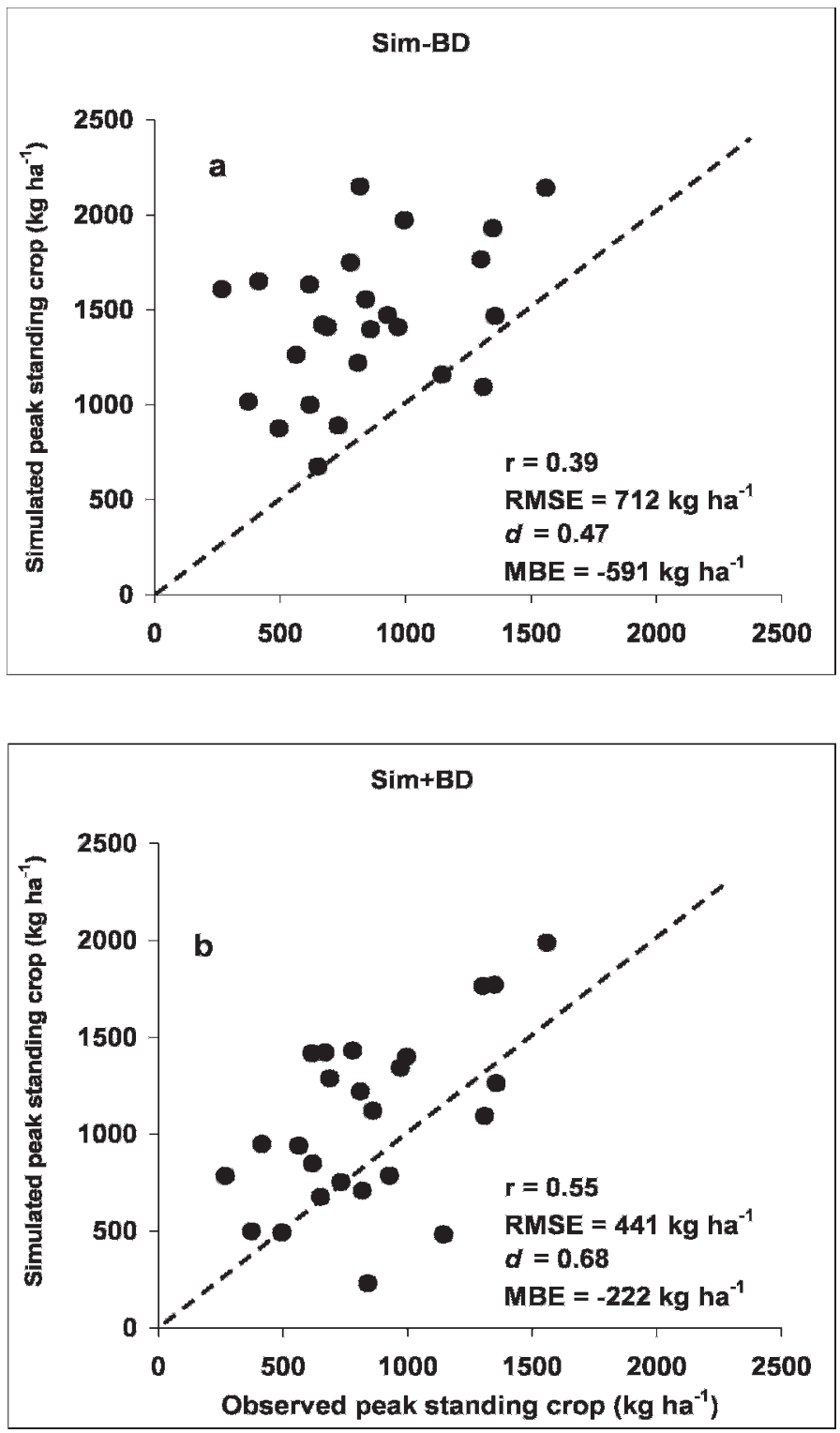

Figure 5. Simulated and observed peak standing crop for no soil compaction (a) and soil compaction (b) effects. RMSE indicates root mean square error; MBE, mean bias error.

rate, among others. In this study, we have directly used the treatment-measured BD for simulating the soil compaction effect on forage growth. The alternative of predicting the future $\mathrm{BD}$ change as a function of soil texture and trampling load, among others, remains a challenge for research. Further, though equation 2 has been found in this study to modify the GrRate in a manner that improved forage growth simulation, its prediction success would depend on the sensitivity of the forage type to $\mathrm{BD}$ change. Presumably, the general form of equation 2 may be valid, but the coefficients may differ, depending on the type of vegetation at a given location. Here, too, there is paucity of data, and further research attention is required to calibrate the equation for different ecological zones.

One important justification of model development is its application to explore management options that may not be easily tested or readily implemented under field conditions. As an example, we used the model to simulate a 20-year (1960-
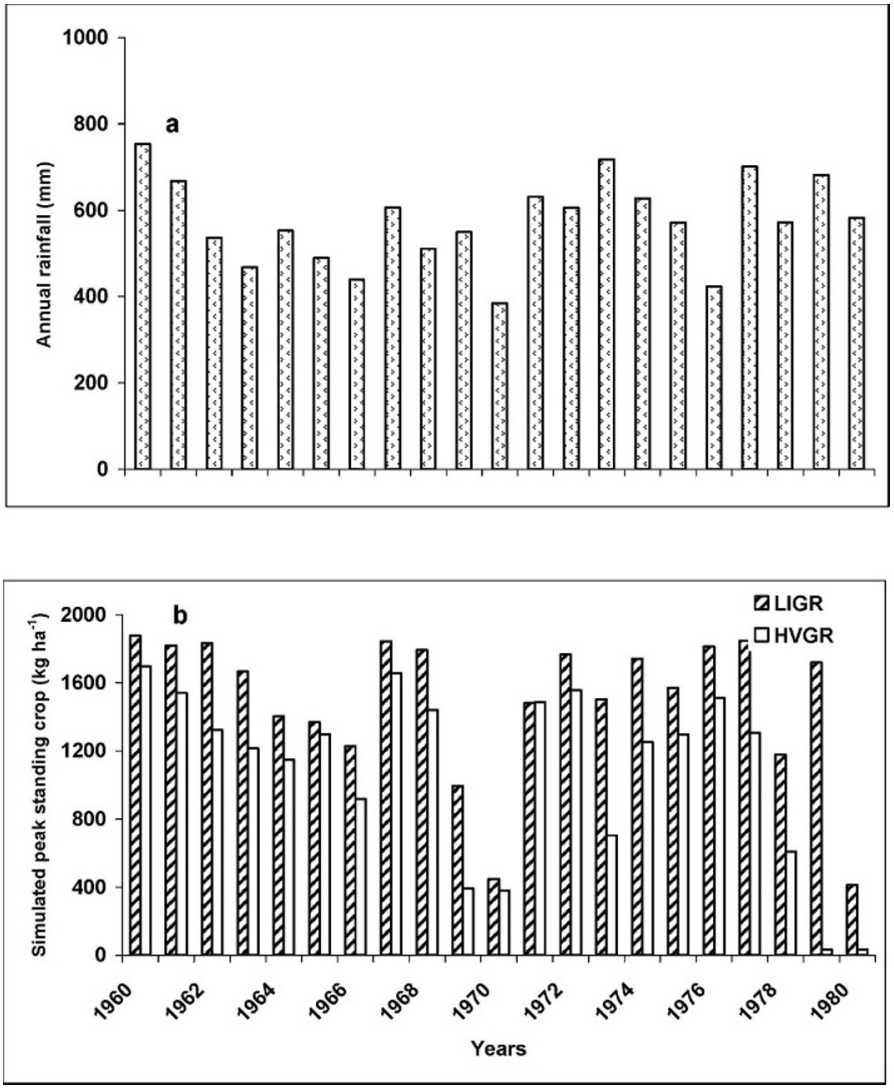

Figure 6. Annual rainfall during the simulation period (a) and the simulated peak standing crop for light and heavy grazing conditions (b).

1980) growth of the WSG-forb mixture at Ft. Supply in the case where the low stocking zone was converted to a high stocking zone. We assumed that the $\mathrm{BD}$ increased linearly from the initial value of $1.61 \mathrm{~g} \cdot \mathrm{cm}^{-3}$ to the high stock value of $1.70 \mathrm{~g} \cdot \mathrm{cm}^{-3}$ over a period of $5 \mathrm{yr}$. The plant and soil parameters were adjusted according to the $\mathrm{BD}$ increase. The simulated results for Sim+BD showed that reductions in forage growth could occur over time (Fig. 6). The average forage production, if the low stocking were continued for the $20 \mathrm{yr}$, would be $1491 \mathrm{~kg} \cdot \mathrm{ha}^{-1}$, but if converted to heavy grazing, the average production would fall to $1085 \mathrm{~kg} \cdot \mathrm{ha}^{-1}$. Whereas scenarios may be expensive and time consuming to experiment, such simulations could help shed light on the possible consequences of high stocking rates on forage growth.

We conclude that the ability to simulate the effect of soil compaction on forage growth is a further improvement in our ability to predict long-term effects of stocking rates on forage growth and hence rangeland management. This is because the determination of appropriate stocking rates for sustained rangeland use requires foreknowledge of forage growth potential and the likely changes in growth due to deterioration of soil condition. The enhanced GPFARM-Range model thus provides a tool for investigating the effects of soil water, temperature, grazing preference, and soil compaction on forage growth. Application of the enhanced model to the situation of Ft. Supply, Oklahoma, indicted that though forage growth was largely determined by rainfall, prolonged high stocking rates $\left(3 \mathrm{ha} \cdot\right.$ steer $\left.^{-1}\right)$ could lead to the reduction in forage growth in the long term. 


\section{MANAGEMENT IMPLICATIONS}

The long-term effects of high stocking rates on rangeland condition have been debated for years but with a general acceptance of high stocking rate causing a deteriorating ecological condition. We have shown that by modeling changes to soil properties under high stocking rates observed losses in forage production can be predicted. The ability to simulate the effect of soil compaction on forage growth is a further improvement in our ability to predict long-term effects of stocking rates on forage growth and hence rangeland management. This is because the determination of appropriate stocking rates for sustained rangeland use requires foreknowledge of forage growth potential and the likely changes in growth due to deterioration of soil condition. Modeling, in this case with GPFARM-Range, provides that foreknowledge that can determine the best management for reducing deterioration of rangeland conditions.

\section{LITERATURE CITED}

Abdel-Magid, A. H., M. J. Trlica, and R. H. HaRt. 1987. Soil and vegetation responses tosimulated trampling. Journal of Range Management 40:303306.

Ahuja, L. R., J. D. Hanson, K. W. Rojas, M. J. Shaffer, and L. Ma [eds.]. 2000. Root Zone Water Quality Model: modeling the management effects on water quality and crop production. Highland Ranch, CO, USA: Water Resources Publications LLC. $372 p$.

Andales, A. A., J. D. Derner, L. R. Ahuja, and R. H. Hart. 2006. Strategic and tactical prediction of forage in Northern Mixed-Grass Prairie. Rangeland Ecology \& Management 59:576-584.

Andales, A. A., J. D. Derner, P. N. S. Bartling, L. R. Ahuja, G. H. Dunn, R. H. Hart, and J. D. HANSon. 2005. Evaluation of GPFARM for simulation of forage production and cow-calf weights. Rangeland Ecology \& Management 58:247-255.

Assouline, S. 2006. Modeling the relationship between the soil bulk density and water retention curve. Vadose Zone Journal 5:554-563.

Barton, H., W. G. McCully, H. M. Taylor, and J. E. Box, JR. 1966. Influence of soil compaction on emergence and first year growth of seeded grasses. Journal of Range Management 19:118-121.

BATTIKHI, A. M., AND A. A. Suleiman. 1999. Effect of tillage system on soil strength and bulk density of vertisols. Journal of Agronomy and Crop Science 183:81-89.

BLACKBURN, W. H. 1975. Factors influencing infiltration and sediment production of semi-arid rangelands in Nevada. Water Resource Research 11:929-937.

Briske, D. D., J. D. Derner, J. R. Brown, S. D. Fuhlendorf, W. R. Teague, K. M. Havstad, R. L. Gillen, A. H. Ash, and W. D. Willms. 2008. Rotational grazing on rangelands: reconciliation of perception and experimental evidence. Rangeland Ecology \& Management 61:3-17.

BRooks, R. H., AND A. J. CoReY. 1964. Hydraulic properties of porous media. Hydrology Paper 3. Fort Collins, CO, USA: Department of Civil Engineering, Colorado State University. $27 \mathrm{p}$

DerneR, J. D., and R. D. Hart. 2007. Grazing-induced modifications to peak standing crop in northern mixed prairie. Rangeland Ecology \& Management 60:270-276

Donkor, N. T., J. V. Gedir, R. J. Hudson, E. W. Bork, D. S. Chanasyk, and M. A. Naeth. 2002. Impacts of grazing systems on soil compaction and pasture production in Alberta. Canadian Journal of Soil Science 82:1-8.

DreWRY, J. J. 2008. Soil compaction in pasture grazing systems. Available at: http://www.scitopics.com/Soil_compaction_in_pasture_grazing_systems.html. Accessed 9 September 2009.

Farahani, H. J., AND L. R. AhuJA. 1996. Evapotranspiration modeling of partial canopy/residue-covered fields. Transactions of American Society of Agricultural Engineers 39:2051-2064.

Gillen, R. L., AND P. L. Sims. 2004. Stocking rate, precipitation, and herbage production on sand sagebrush-grassland. Journal of Range Management $57: 148-152$

Green, W. H., AND G. A. Ampt. 1911. Studies on soil physics, part I, the flow of air and water through soils. Journal of Agricultural Science 4:1-24.

Hanson, C. L., A. R. Kuhlman, C. J. ERickson, and J. K. Lewis. 1970. Grazing effects on runoff and vegetation on Western Dakota rangeland. Journal of Range Management 23:418-420.

Hanson, J. D., J. W. Skiles, and W. J. Parton. 1987. Plant components. In: J. Wight and J. W. Skiles [EDS.]. SPUR: Simulation of Production and Utilization of Rangelands. Documentation and user guide. USDA ARS 63. Springfield, VA, USA: National Technical Information Service. 372 p.

Hargreaves, G. H., and Z. A. Samani. 1982. Estimating potential evapotranspiration. Journal of Irrigation and Drainage Engineering 108:223-230.

Holechek, J. L., H. Gomez, F. Molinar, and D. Galt. 1999. Grazing studies: what we've learned. Rangelands 21:12-16.

KüchleR, A. W. 1975. Potential natural vegetation of the conterminous United States [Map]. New York, NY, USA: American Geographic Society. 116 p.

Mapfumo, E., D. S. Chanasyk, M. A. Naeth, and V. S. Baron. 1998. Forage growth and yield components as influenced by subsurface compaction. Agronomy Journal 90:805-812.

Milchunas, D. G., and W. K. Lauenroth. 1993. Quantitative effects of grazing on vegetation and soils over a global range of environments. Ecological Monographs 63:327-366.

Rhoades, E. D., L. F. Locke, H. M. TayloR, and E. H. Mcllvain. 1964. Water intake on sandy range as affected by 20 years of differential cattle stocking rates. Journal of Range Management 17:185-190.

Shuttleworth, W. J., and J. S. Wallace. 1985. Evaporation from sparse crops: an energy combination theory. Quarterly Journal of the Royal Meteorological Society 111:839-855.

Wilımott, C. J. 1981. On the validation of models. Physical Geography 2:184-194. 